\title{
Redescription of the advertisement call of Brachycephalus tridactylus (Anura: Brachycephalidae)
}

\author{
Marcos R. Bornschein ${ }^{1,2}$, Mario M. Rollo Jr. ${ }^{1}$, Marcio R. Pie ${ }^{2,3}$, André E. Confetti ${ }^{4}$, and Luiz F. \\ Ribeiro $^{2,5}$ \\ ${ }^{1}$ Universidade Estadual Paulista (UNESP), Campus do Litoral Paulista. 11330-900, São Vicente, SP, Brazil. E-mail: bornschein. \\ marcao@gmail.com. \\ 2 Mater Natura, Instituto de Estudos Ambientais, 80250-020, Curitiba, Paraná, PR, Brazil. \\ ${ }^{3}$ Departamento de Zoologia, Universidade Federal do Paraná. 81531-980, Curitiba, PR, Brazil. \\ ${ }^{4}$ Programa de Pós-Graduação em Zoologia, Universidade Federal do Paraná. 81531-980, Curitiba, PR, Brazil. \\ ${ }^{5}$ Escola de Ciências da Vida, Pontifícia Universidade Católica do Paraná. 80215-901, Curitiba, PR, Brazil.
}

\begin{abstract}
Redescription of the advertisement call of Brachycephalus tridactylus (Anura: Brachycephalidae). Miniaturized frogs of the genus Brachycephalus have restricted geographical distributions throughout the Atlantic Forest. Ecological data for most species are scarce and advertisement calls have been described for only 12 of the 36 known species, including $B$. tridactylus. The considerable duration of note length of the advertisement call of $B$. tridactylus has been mentioned in comparative studies of vocalizations in Brachycephalus. The single original recording of B. tridactylus, together with recordings made in March 2016 at the type locality, were analyzed to document any variation and redescribe the advertisement call of the species. In the recent recordings of B. tridactylus, the average length of the call is $50.8 \mathrm{~s}$ and the call is composed of 10-13 notes emitted at a note rate of 3.7-8.3 notes per min. The notes are isolated and composed of 1-3 pulses, with the note duration varying from $0.002-0.021 \mathrm{~s}$. These values are not consistent with the original description of the call of $B$. tridactylus. The note duration is $89 \%$ shorter and the original description does not include notes with 1-3 pulses. The notes of $B$. tridactylus have few pulses, whereas those of $B$. ephippium have several. The advertisement call of $B$. tridactylus differs from that of $B$. albolineatus and B. mirissimus by having only isolated notes.
\end{abstract}

Keywords: bioacoustics, Brazilian Atlantic Forest, isolated notes, note-centered approach.

\section{Resumo}

Redescrição do canto de anúncio de Brachycephalus tridactylus (Anura: Brachycephalidae). Os anuros miniaturizados do gênero Brachycephalus apresentam distribuição geográfica restrita ao longo da Floresta Atlântica. Dados ecológicos da maioria das espécies são escassos e cantos de anúncio foram descritos de apenas 12 das 36 espécies conhecidas, incluindo B. tridactylus. A considerável duração das notas do canto de anúncio de B. tridactylus foi mencionada em um estudo comparativo de vocalizações de Brachycephalus. A única gravação original de B. tridactylus e

Received 11 December 2018

Accepted 25 March 2019

Distributed June 2019 


\begin{abstract}
gravações feitas em março de 2016 na localidade tipo foram analisadas para documentar alguma variação e redescrever o canto de anúncio da espécie. Nas recentes gravações de $B$. tridactylus, o canto de anúncio dura em média 50,8 s e é composto por 10-13 notas emitidas a uma taxa de 3,7-8,3 notas por min. As notas são isoladas, compostas por 1-3 pulsos e duram de 0,002 a 0,021 s. Esses valores não são consistentes com a descrição original do canto de anúncio de $B$. tridactylus. A duração da nota é $89 \%$ menor e a descrição original não inclui notas com 1-3 pulsos. As notas de $B$. tridactylus têm poucos pulsos, enquanto que as de $B$. ephippium têm vários. $\mathrm{O}$ canto de anúncio de B. tridactylus difere daquele de B. albolineatus e B. mirissimus por ter apenas notas isoladas.
\end{abstract}

Palavras-chave: abordagem centrada em notas, bioacústica, Floresta Atlântica brasileira, notas isoladas.

\section{Introduction}

Brachycephalus currently contains 36 species (Frost 2018) of small toads $(<2.5 \mathrm{~cm}$ in body length) endemic to the Atlantic Forest of Brazil. The smallest species of the genus are among the smallest terrestrial vertebrates in the world (Rittmeyer et al. 2012); they have minute bodies and a reduction in the number of digits (Hanken and Wake 1993, Yeh 2002, Clemente-Carvalho et al. 2009). Some species have highly restricted geographical distributions (Bornschein et al. 2016). The bright colors of many species may be related to aposematism in association with neurotoxins in the skin (e.g., Sebben et al. 1986, Pires Jr. et al. 2002, 2003, 2005).

Most species of Brachycephalus are found on the forest floor at high altitudes in the mountains of the Serra do Mar in the Atlantic Forest Domain (up to $1900 \mathrm{~m}$ a.s.l.; Bornschein et al. 2016). Although all species are diurnal and locally abundant (Bornschein et al. 2018), they are difficult to find owing to their restricted ranges and microendemism. In the last decade, intensified fieldwork has led to the description of 23 species (Frost 2018), but data on natural history lag behind the rate of new species descriptions. Advertisement calls have been described for 12 of 36 species (33\%): B. actaeus Monteiro, Condez, Garcia, Comitti, Amaral, and Haddad, 2018 (Monteiro et al. 2018a); B. ephippium (Spix, 1824) (Pombal et al. 1994, Goutte et al. 2017); B. albolineatus Bornschein,
Ribeiro, Blackburn, Stanley, and Pie, 2016 (Bornschein et al. 2018); B. crispus Condez, Clemente-Carvalho, Haddad, and Reis, 2014 (Condez et al. 2014); B. darkside Guimarães, Luz, Rocha, and Feio, 2017 (Guimarães et al. 2017); B. hermogenesi (Giaretta and Sawaya, 1998) (Verdade et al. 2008); B. mirissimus Pie, Ribeiro, Confetti, Nadaline, and Bornschein, 2018 (Pie et al. 2018); B. olivaceus Bornschein, Morato, Firkowski, Ribeiro and Pie, 2015 (Monteiro et al. 2018b); B. pitanga Alves, Sawaya, Reis, and Haddad, 2009 (Araújo et al. 2012, Tandel et al. 2014, Goutte et al. 2017); B. quiririensis Pie and Ribeiro, 2015 (Monteiro et al. 2018b); B. sulfuratus Condez, Monteiro, Comitti, Garcia, Amaral, and Haddad, 2016 (Condez et al. 2016); and B. tridactylus Garey, Lima, Hartmann, and Haddad, 2012 (Garey et al. 2012).

Brachycephalus tridactylus was described based on a type series of seven specimens collected at the type locality, Reserva Particular do Patrimônio Natural Salto Morato, Paraná, southern Brazil (Bornschein et al. 2015). The species is a micro-endemic frog that occupies an estimated 41 ha of montane forests in the Atlantic Forest (Bornschein et al. 2016). The description of the advertisement call of the new species was based on the calls of 17 individuals (Garey et al. 2012). Bornschein et al. (2018) reported that the note length of $B$. tridactylus is greater than that of $B$. albolineatus. To confirm this apparent difference in the duration of notes, the original recordings of B. tridactylus were reanalyzed and 
compared with our recent recordings of the species. A description of the advertisement call of B. tridactylus follows.

\section{Materials and Methods}

Original Recordings of B. tridactylus from

Garey et al. (2012)

Only one of the original recordings of Brachycephalus tridactylus described by Garey et al. (2012) was deposited in the sound collection of Fonoteca Neotropical Jacques Vielliard (FNJV 0032950) and this recording was made by André M.X. Lima. The other recordings were lost with the theft of the personal computer on which the audio files were stored (A. M. X. Lima pers. comm. 2018).

Our Recordings of B. tridactylus

We visited the type locality of Brachycephalus tridactylus (sensu Bornschein et al. 2015) to record the frogs on 10 March 2016 at the Reserva Particular do Patrimônio Natural Salto Morato (RPPN-SM; 2508'09" S, 48 $17^{\prime} 59^{\prime \prime} \mathrm{W}$ ) in the municipality of Guaraqueçaba and state of Paraná in southern Brazil. Voucher specimens are deposited in the Museu de História Natural Capão da Imbuia (MHNCI 10294, 10730), Curitiba, state of Paraná, Brazil, and in the Célio F. B. Haddad collection (CFBH 43887-9), Departamento de Zoologia, Universidade Estadual Paulista, Campus de Rio Claro, state of São Paulo, Brazil.

Calls were recorded between 14:00 and 16:45 $\mathrm{h}$ when the air temperature was $24.0^{\circ} \mathrm{C}$, the soil temperature was $20.9^{\circ} \mathrm{C}$, and the relative humidity was 99\%. Numbered ribbons were affixed to the vegetation above the individuals recorded to determine whether new recordings were from the same or a new individual. Calls were recorded with digital recorders (Sony PCM-D50 and PCM-M10) with a sampling frequency rate of $44.1 \mathrm{kHz}$ and 16-bit resolution, connected to Sennheiser ME 66 microphones.
All recordings are deposited in MHNCI (035051). We shifted the position of the microphone slightly (along $1 \mathrm{~m}^{2}$ ) and used the level of the input signal of the recording to locate the calling frog. Consequently, the intensity of audio capture during recording varies slightly.

\section{Advertisement Call Analysis}

Sound samples were analyzed with Raven Pro 1.5.0 Build 40 (Bioacoustics Research Program 2017). Time domain variables were measured from oscillograms and frequency domain variables were measured from spectrograms. Spectrogram parameters were defined with a 256-point Fast Fourier Transform (FFT), a 3-dB Filter bandwidth of $492 \mathrm{~Hz}$, DFT 256 samples, Hann window, $50 \%$ overlap, and spectrogram color schemes of Standard Gamma II and Jet Black. Final spectrograms, as well as diagnostic plots, were generated using the seewave package, v. 2.1.0 (Sueur 2018) in R version 3.5.1 (R Development Core Team 2018) with the same window size and overlap settings as in Raven Pro.

The advertisement calls were described per the parameters, criteria, and the note-centered approach of Köhler et al. (2017). Likewise, we adopted the general presentation order and particularities in Köhler's parameters, as presented in Bornschein et al. (2018). We considered all parameters used in describing the call of Brachycephalus albolineatus (Bornschein et al. 2018), but we used only those applicable to the call characteristics of $B$. tridactylus, as follow: (1) call duration (s); (2) note rate (notes per min); (3) number of notes per call; (4) number of pulses per notes; (5) note duration (s); (6) inter-note interval (s); (7) note dominant frequency $(\mathrm{kHz})$; $(8)$ highest frequency $(\mathrm{kHz})$; and (9) lowest frequency $(\mathrm{kHz})$. Call duration is defined as the time span from the beginning of the first note to the end of the last note emitted in a call. Note rate is the number of notes emitted from the first note to the beginning of the last note (not including the last note). The inter-note 
interval is the time interval between two consecutive notes. The highest and lowest frequencies were measured from notes. All measurements were made from the fundamental frequency. Additional information on measurements is available in Figure 1 of Bornschein et al. (2018).

\section{Results}

\section{Analysis of the Original Recording of Brachycephalus tridactylus}

In the original recording of the call of Bracycephalus tridactylus (FNJV 0032950), the call lasted $50 \mathrm{~s}$ and included eight notes. The entire recording is noisy (signal-to-noise ratio of $-6 \mathrm{~dB}$ ) and has more signals that are not associated with the notes of $B$. tridactylus. There is no acoustic information above $10 \mathrm{kHz}$. The sampling rate of this recording is set to $48 \mathrm{kHz}$; thus, it seems that the audio was low-pass filtered with a cutoff frequency of $10 \mathrm{kHz}$.

The notes of the recording that we heard overlap with other signals, probably reverberation and/or environmental noise (e.g., rain noise; Figure 1A). This prevented us from determining the note length and recognizing and measuring other acoustic parameters, such as the number of pulses and upper and lower frequency limits. There is a concentration of energy at the beginning of the note emission, coincident with the auditory recognition of the note, but the energy is prolonged and attenuates gradually (Figure 1A).

Analysis of Our Recordings of Brachycephalus tridactylus

We recorded calls of 15 individual Brachycephalus tridactylus; five of the frogs were collected as vouchers. However, the number of individuals analyzed for each call parameter varied from 5-14 individuals (Table 1). A total of 17 separate recordings (MHNCI 035-051) were deposited in the collection.
The calls that we recorded are of the same type as that of the original recording (FNJV 0032950). The energy signals match our recorded sounds (Figure 1B) but they have a different pattern than those of the original recording (Figure 1A). Consequently, we present a redescription of the advertisement call of the species. The average length of the advertisement call of Brachycephalus tridactylus is $50.793 \mathrm{~s} \mathrm{( \pm}$ 11.708 s; Table 1; Figure 2A). After emitting a call, the frog might remain silent for several minutes-sometimes for more than $30 \mathrm{~min}$. The note rate is $3.745-8.330$ notes per min $(=5.159$ \pm 1.347 notes per min; Table 1 ). Advertisement calls of B. tridactylus are composed of 10-13 notes $(=11.333 \pm 0.976$ notes; Table 1 ; Figure $1)$. The call consists only of isolated notes. The notes have $1-3$ pulses $(=1.968 \pm 0.542$ pulse; Figures $1 \mathrm{~B}$ and $2 \mathrm{~B}-\mathrm{D}$; Table 1) and the note duration varies from $0.002-0.021 \mathrm{~s}(=0.012 \pm$ $0.005 \mathrm{~s}$; Table 1). The average inter-note interval is $5.325 \mathrm{~s}(3.269-9.806 \mathrm{~s} \pm 1.447 \mathrm{~s}$; Table 1). The dominant frequency varies from 4.134$5.426 \mathrm{kHz}(=5.062 \pm 0.303 \mathrm{kHz}$; Table 1$)$. The highest frequency of the notes varies from $5.682-7.488 \mathrm{kHz}(=6.445 \pm 0.447 \mathrm{kHz})$, whereas the lowest frequency ranges from 2.718-4.605 $\mathrm{kHz}(=3.579 \pm 0.474 \mathrm{kHz}$; Table 1$)$. There are no harmonics; therefore, the measurements are of fundamental frequencies.

The number of pulses per note tends to be constant in the advertisement calls and includes only one or two pulses; however, in some advertisement calls, notes might have two or three pulses (Table 2). Intra-individual variation in the number of pulses per note is presented in Table 2.

\section{Discussion}

We have determined that the acoustic energy of the notes in the original recording (FNJV 0032950) overlaps with reverberation and/or environmental noise, thereby preventing us, as well as Garey et al. (2012), to provide a complete description of the advertisement call of 

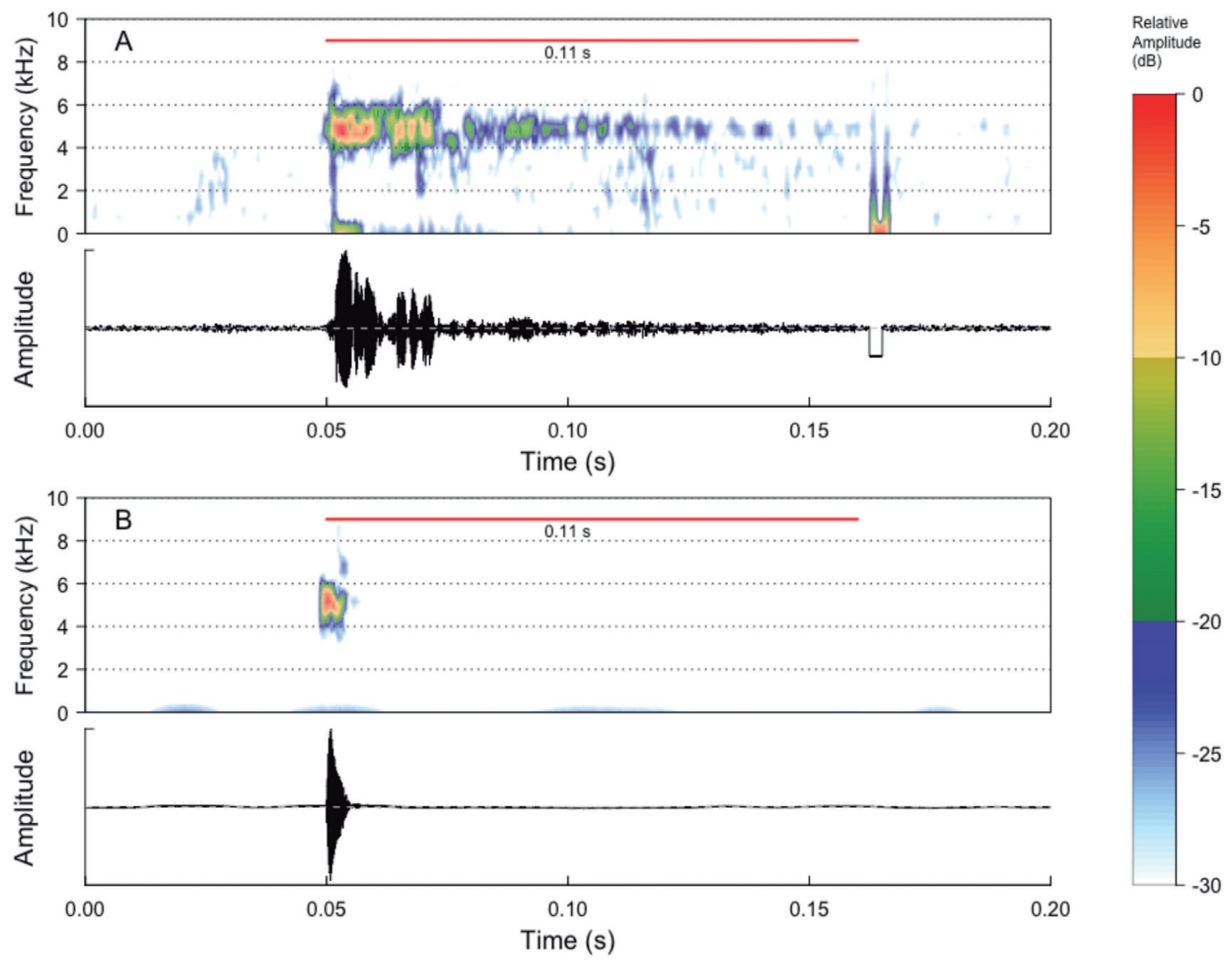

Figure 1. Spectrograms of Brachycephalus tridactylus produced for comparison between the audio recording in the FNJV (0032950) and one of our own recordings, built with the same parameters. A. Example of one note from the original recording (FNJV 0032950). Notice that it overlaps with other signals. B. Example of a note

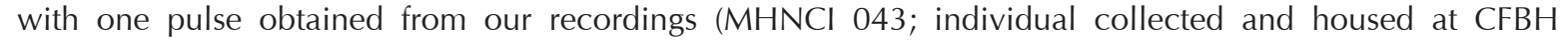
43887). The horizontal red bar represents the mean of note duration $(0.11 \mathrm{~s})$ of the species according to the description in Garey et al. (2012). FFT size of 128 points, Hann window, overlap of 88\%.

Brachycephalus tridactylus. Thus, the notes described in Figures 3A and B of Garey et al. (2012) and shown in Figure 1A are overlapped by the energy of notes representing reverberation and/or noise.

The original description of advertisement call of Brachycephalus tridactylus stated that the call had "one single short note $(0.11 \pm 0.02 \mathrm{~s})$, with a dominant frequency of $4.8 \pm 0.2 \mathrm{kHz}$. The frequency range is $3.2-6.4 \mathrm{kHz}$ at the beginning of the note, whereas at the end it decreases to 4.3-5.3 kHz (Figures 3A,B)" (Garey et al. 2012; Table 1). The note duration is $89 \%$ shorter (Figure 1) in our recordings of $B$. tridactylus and ranges from $0.002-0.021 \mathrm{~s}(\bar{x}=0.012 \mathrm{~s} \pm 0.005$ s). We also have documented the existence of notes with 1-3 pulses, a feature not observed in the original description (Garey et al. 2012). Condez et al. (2016) mentioned that B. tridactylus has notes with 1-3 pulses based on Garey et al. 

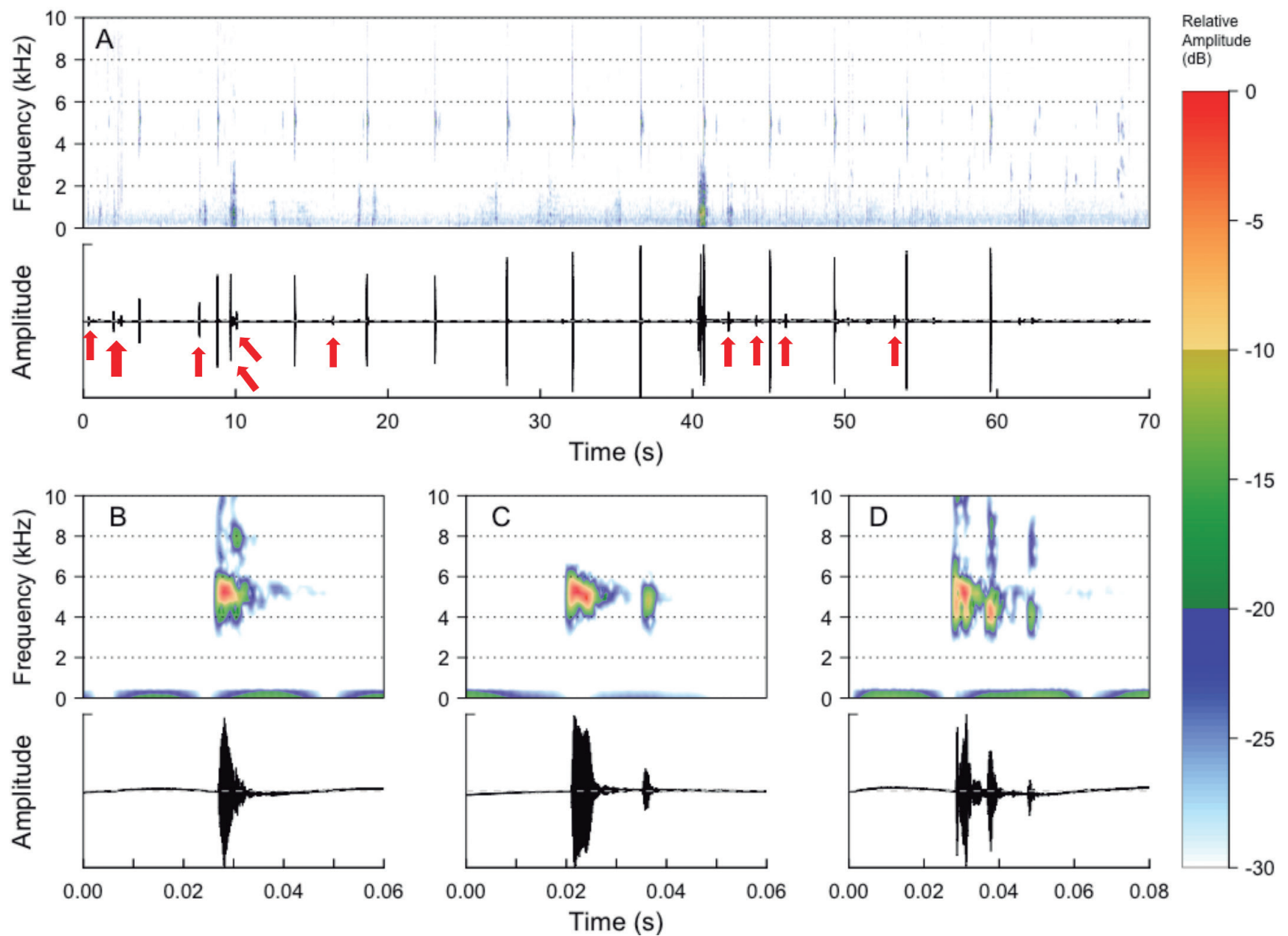

Figure 2. Example of an entire advertisement call and also notes of other advertisement calls of Brachycephalus tridactylus. A. Entire advertisement call (MHNCI 049; individual not collected), with 13 notes; arrows

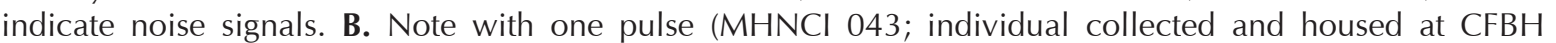
43887). C. Note with two pulses (MHNCI 046; individual collected and housed at MHNCI 10730). D. Note with three pulses ( $\mathrm{MHNCl} \mathrm{040;} \mathrm{individual} \mathrm{collected} \mathrm{and} \mathrm{housed} \mathrm{at} \mathrm{CFBH} 43889$ ). Spectrograms produced with FFT size of 128 points, Hann window, and overlap of $88 \%$.

(2012), but this information does not appear in Garey et al. (2012). Last, we did not record the gradual decrease in frequency described by Garey et al. (2012).

Short notes are characteristic of all species of the Brachycephalus pernix Group, which includes species from southern Brazil. The mean note lengths of this group are, as follow: $0.010 \mathrm{~s}$ for B. mirissimus (Pie et al. 2018); $0.012 \mathrm{~s}$ for $B$. tridactylus (this study); $0.020 \mathrm{~s}$ for $B$. albolineatus (Bornschein et al. 2018); $0.04 \mathrm{~s}$ for B. actaeus (Monteiro et al. 2018a); $0.04 \mathrm{~s}$ for B. olivaceus
(Monteiro et al. 2018b); and $0.05 \mathrm{~s}$ for $B$. quiririensis (Monteiro et al. 2018b). Pulsed notes are characteristic of all species of Brachycephalus (compilations in Monteiro et al. 2018a,b, Pie et al. 2018, and this study). Members of the B. ephippium and B. hermogenesi Groups have notes with several pulses, as follow: 5-8 in B. darkside (Guimarães et al. 2017); 5-15 in B. ephippium (Pombal Jr. et al. 1994); 7-11 in B. sulfuratus (Condez et al. 2016); 7-12 in B. crispus (Condez et al. 2014); and 7-14 in $B$. pitanga (Tandel et al. 2014). These values are 
Table 1. Measurements of acoustic parameters of the advertisement call of Brachycephalus tridactylus. ${ }^{1} \mathrm{~N}=17$ individuals. ${ }^{2} N=5$ call durations are fragments of the entire call (Table 2). ${ }^{3}$ Same as note duration if applicable the call-centered approach of Köhler et al. (2017). ${ }^{4}$ Includes notes counted before the beginning of the recording (Table 2). ${ }^{5}$ Not applicable under note-centered approach used here. ${ }^{6}$ The original description stated that "frequency range is $3.2-6.4 \mathrm{kHz}$ at the beginning of the note, whereas at the end it decreases to 4.3-5.3 kHz".

\begin{tabular}{|c|c|c|c|c|c|c|c|c|}
\hline \multirow{3}{*}{ Variable } & \multicolumn{5}{|c|}{ Present description } & \multicolumn{3}{|c|}{$\begin{array}{l}\text { Original description } \\
\text { (Garey et al. 2012) }^{1}\end{array}$} \\
\hline & \multirow{2}{*}{ Range } & \multirow{2}{*}{ Mean } & \multirow{2}{*}{ SD } & \multicolumn{2}{|c|}{$N$} & \multirow{2}{*}{ Range } & \multirow{2}{*}{ Mean } & \multirow{2}{*}{ SD } \\
\hline & & & & Samples & Individuals & & & \\
\hline Call duration (s) & $33.713-65.937$ & 50.793 & 11.708 & $7^{2}$ & 6 & -3 & -3 & -3 \\
\hline $\begin{array}{l}\text { Call rate (call per } \\
\text { second) }\end{array}$ & - & - & - & - & - & $?$ & 0.16 & 0.03 \\
\hline $\begin{array}{l}\text { Note rate (notes per } \\
\text { minute) }\end{array}$ & $3.745-8.330$ & 5.159 & 1.347 & 17 & 14 & - & - & - \\
\hline $\begin{array}{l}\text { Number of notes } \\
\text { per call }\end{array}$ & $10-13^{4}$ & 11.333 & 0.976 & 7 & 6 & -5 & -5 & -5 \\
\hline $\begin{array}{l}\text { Number of pulses } \\
\text { per notes }\end{array}$ & $1-3$ & 1.968 & 0.542 & 62 & 8 & 0 & - & - \\
\hline Note duration (s) & $0.002-0.021$ & 0.012 & 0.005 & 49 & 7 & $?$ & 0.11 & 0.02 \\
\hline Inter-note interval (s) & $3.269-9.806$ & 5.325 & 1.447 & 51 & 10 & -5 & -5 & -5 \\
\hline $\begin{array}{l}\text { Note dominant } \\
\text { frequency }(\mathrm{kHz})\end{array}$ & $4.134-5.426$ & 5.062 & 0.303 & 44 & 5 & $?$ & 4.8 & 0.2 \\
\hline $\begin{array}{l}\text { Highest frequency } \\
(\mathrm{kHz})\end{array}$ & $5.682-7.488$ & 6.445 & 0.447 & 54 & 12 & -6 & - & - \\
\hline $\begin{array}{l}\text { Lowest frequency } \\
(\mathrm{kHz})\end{array}$ & $2.718-4.605$ & 3.579 & 0.474 & 54 & 12 & -6 & - & - \\
\hline
\end{tabular}

Table 2. Number of pulses per note (separated by commas) of the advertisement calls of Brachycephalus tridactylus.

\begin{tabular}{|c|c|c|}
\hline $\begin{array}{l}\text { Individual (call } \\
\text { voucher number) }\end{array}$ & Number of pulses per notes & $\begin{array}{c}\text { Number of notes heard being emitted before } \\
\text { recording the advertisement call }\end{array}$ \\
\hline $1(\mathrm{MHNCl} 035)$ & $2,3,2,2,2,2$ & 4 \\
\hline $2(\mathrm{MHNCl} 040)$ & $2,2,2,2,3,3,3,2$ & 3 \\
\hline $2(\mathrm{MHNCl} 041)$ & $2,2,2,2,2,2,2$ & 4 \\
\hline $3(\mathrm{MHNCl} 042)$ & $3,2,2$ & $?$ \\
\hline $4(\mathrm{MHNCl} 043)$ & $1,1,1,1,1,1,1,1,1,1$ & 2 \\
\hline $5(\mathrm{MHNCl} 044)$ & 3 & $?$ \\
\hline $6(\mathrm{MHNCl} 045)$ & $2,2,2,2,2,2,2,2,2,2$ & 2 \\
\hline 7 (MHNCI 046) & $2,2,2,2,2,2,2,2,2,2,2$ & 1 \\
\hline 8 (MHNCI 049) & $2,2,2,2,2,2,2,2,2,2,2,2,2$ & 0 \\
\hline
\end{tabular}


much higher than those of the $B$. pernix Group: 1-3 in B. albolineatus (Bornschein et al. 2018), B. mirissimus (Pie et al. 2018), and B. tridactylus (this study); 2-3 in B. actaeus (Monteiro et al. 2018a) and B. olivaceus (Monteiro et al. 2018b), and 3-4 in B. quiririensis (Monteiro et al. 2018b). Although Verdade et al. (2008) did not report the pulses in the notes of the call of $B$. hermogenesi of the $B$. didactylus Group, their figures $6 \mathrm{~B}$ and $\mathrm{C}$ seem to depict at least two pulses.

The inter- and intra-individual variation in the number of notes and pulses per note in the advertisement calls of Brachycephalus tridactylus described here might reflect individual's arousal level. Similar variation in the numbers of notes and pulses was reported for B. albolineatus (Bornschein et al. 2018) and a possible relationship with individual arousal was also suggested.

In Brachycephalus albolineatus and $B$. mirissimus (Pie et al. 2018), the advertisement calls are composed of isolated notes and note groups (sensu Köhler et al. 2017), in contrast with the advertisement call of B. tridactylus, for which we recorded only isolated notes. The advertisement calls of $B$. actaeus (Monteiro et al. 2018a), B. quiririensis, and B. olivaceus (Monteiro et al. 2018b) were described with the call-centered approach of Köhler et al. (2017) by which a single note represents the call, instead of the note-centered approach of the present description. Thus, the possibility that the calls of these species include isolated notes and note groups cannot be assessed. A note group emitted by a Brachycephalus would invariable be treated as two notes (or more, if the case) under the callcentered approach.

Brachycephalus communication is a topic of increasing interest and we are still far from a comprehensive understanding of their evolution. Much still can be found in terms of structural and temporal variation in the advertisement calls of the species of the genus, as well as possible the phylogenetic distribution of this variation.

\section{Acknowledgments}

Fieldwork was funded by Fundação Grupo Boticário de Proteção à Natureza, through a project (A0010_2014) conducted by Mater Natura-Instituto de Estudos Ambientais. The Fundação Grupo Boticário de Proteção à Natureza also provided logistic support for research in the type locality of Brachycephalus tridactylus. ICMBIO-SISBIO provided collecting permits. Felipe L. Toledo provided access to the original recording of B. tridactylus in FNJV. André M. X Lima sent us an original recording of $B$. tridactylus and provided us with important data about his fieldwork with the species. We are grateful to André M. X Lima and Michel V. Garey for encouraging and facilitating our study. Two anonymous reviewers improved the quality of the text. MRP was supported through a grant from CNPq/MCT (301636/2016-8).

\section{References}

Araújo, C. B. de, T. J. Guerra, M. C. O. Amatuzzi, and L. A. Campos. 2012. Advertisement and territorial calls of Brachycephalus pitanga (Anura: Brachycephalidae). Zootaxa 3302: 66-67.

Bioacoustics Research Program. 2017. Raven Pro: Interactive Sound Analysis Software. Version 1.5. URL: http:// www.birds.cornell.edu/raven.

Bornschein, M. R., R. Belmonte-Lopes, L. F. Ribeiro, G. N. Maurício, and M. R. Pie. 2015. Rectification of the position of the type locality of Brachycephalus tridactylus (Anura: Brachycephalidae), a recently described species from southern Brazil. Zootaxa 4007: 149-150.

Bornschein, M. R., C. R. Firkowski, R. Belmonte-Lopes, L. Corrêa, L. F. Ribeiro, S. A. A. Morato, R. L. AntoniazziJr., B. L. Reinert, A. L. S. Meyer, F. A. Cini, and M. R. Pie 2016. Geographic and altitudinal distribution of Brachycephalus Fitzinger (Anura: Brachycephalidae) endemic to the Brazilian Atlantic Rainforest. PeerJ 4: e2490.

Bornschein, M. R., L. F. Ribeiro, M. M. Rollo Jr., A. E. Confetti, and M. R. Pie. 2018. Advertisement call of Brachycephalusalbolineatus(Anura: Brachycephalidae). PeerJ 6: e5273. 
Clemente-Carvalho, R. B. G., M. M. Antoniazzi, C. Jared, C. F. B. Haddad, A. C. R. Alves, H. S. Rocha, G. R. Pereira, D. F. Oliveira, R. T. Lopes, and S. F. Reis. 2009. Hyperossification in miniaturized toadlets of the genus Brachycephalus (Amphibia: Anura: Brachycephalidae): microscopic structure and macroscopic patterns of variation. Journal of Morphology 270: 12851295.

Condez, T. H., R. B. G. Clemente-Carvalho, C. F. B. Haddad, and S. F. Reis. 2014. A new species of Brachycephalus (Anura: Brachycephalidae) from the highlands of the Atlantic Forest, southeastern Brazil. Herpetologica 70: 89-99.

Condez, T. H., J. P. C. Monteiro, E. J. Comitti, P. C. A. Garcia, I. B. Amaral, and C. F. B. Haddad. 2016. A new species of flea-toad (Anura: Brachycephalidae) from southern Atlantic Forest, Brazil. Zootaxa 4083: 40-56.

Frost, D. R. (ed.). 2018. Amphibian Species of the World: an Online Reference. Version 6.0 (12 March 2018). Electronic Database accessible at http://research.amnh. org/herpetology/amphibia/index.html Museum of Natural History, New York, USA. Captured on 25 November 2018.

Garey, M. V., A. M. X. Lima, M. T. Hartmann, and C. F. B. Haddad. 2012. A new species of miniaturized toadlet, genus Brachycephalus (Anura: Brachycephalidae), from southern Brazil. Herpetologica 68: 266-271.

Goutte, S., M. J. Mason, J. Christensen-Dalsgaard, F. Montealegre-Z, B. D. Chivers, F.A. Sarria-S, M. M. Antoniazzi, C. Jared, L. A. Sato, and L. F. Toledo. 2017. Evidence of auditory insensitivity to vocalization frequencies in two frogs. Scientific Reports 7: 12121.

Guimarães, C. S., S. Luz, P. C. Rocha, and R. N. Feio. 2017. The dark side of pumpkin toadlet: a new species of Brachycephalus (Anura: Brachycephalidae) from Serra do Brigadeiro, southeastern Brazil. Zootaxa 4258: 327344.

Hanken, J. and D. B. Wake. 1993. Miniaturization of body size: organismal consequences and evolutionary significance. Annual Review of Ecology and Systematics 24: 501-519.

Köhler, J., M. Jansen, A. Rodriguez, P. J. R. Kok, L. F. Toledo, M. Emmrich, F. Glaw, C. F. B. Haddad, M.-O. Rödel, and M. Vences. 2017. The use of bioacoustics in anuran taxonomy: theory, terminology, methods and recommendations for best practice. Zootaxa 4251: 1-124.

Monteiro, J. P. C., T. H. Condez, P. C. A. Garcia, E. J. Comitti, I. B. Amaral, and C. F. B. Haddad, 2018a. A new species of Brachycephalus (Anura, Brachycephalidae) from the coast of Santa Catarina
State, southern Atlantic Forest, Brazil. Zootaxa 4407: 483-505.

Monteiro, J. P. C., T. H. Condez, P. C. de A. Garcia, and C. F. B. Haddad. 2018b. The advertisement calls of two species of Brachycephalus (Anura: Brachycephalidae) from southern Atlantic Forest, Brazil. Zootaxa 4415: 183-188.

Pie, M. R., L. F. Ribeiro, A. E. Confetti, M. J. Nadaline, and M. R. Bornschein. 2018. A new species of Brachycephalus (Anura: Brachycephalidae) from southern Brazil. PeerJ 6: e5683.

Pires Jr., O. R., A. Sebben, E. F. Schwartz, S. W. R. Largura, C. Bloch Jr., R. A. V. Morales, and C. A. Schwartz. 2002. Occurrence of tetrodotoxin and its analogues in the Brazilian frog Brachycephalus ephippium (Anura: Brachycephalidae). Toxicon 40: 761-766.

Pires Jr., O. R., A. Sebben, E. F. Schwartz, C. Bloch Jr, R. A. V. Morales, and C. A. Schwartz. 2003. The occurrence of 11-oxotetrodotoxin, a rare tetrodotoxin analogue, in the Brachycephalidae frog Brachycephalus ephippium. Toxicon 42: 563-566.

Pires Jr., O. R., A. Sebben, E. F. Schwartz, R. A. V. Morales, C. Bloch Jr., and C. A. Schwartz. 2005. Further report of the occurrence of tetrodotoxin and new analogues in the Anuran family Brachycephalidae. Toxicon 45: 73-79.

Pombal Jr., J. P., I. Sazima, and C. F. B. Haddad. 1994. Breeding behavior of the pumpkin toadlet, Brachycephalus ephippium (Brachycephalidae). Journal of Herpetology 28: 516-519.

R Development Core Team. 2018. R: A Language and Environment for Statistical Computing. R Foundation for Statistical Computing. URL: https:/www.R-project. org.

Rittmeyer, E. N., A. Allison, M. C. Gründler, D. K. Thompson, and C. C. Austin. 2012. Ecological guild evolution and the discovery of the world's smallest vertebrate. PLoS ONE 7: e29797.

Sebben, A., C. A. Schwartz, D. Valente, and E. G. Mendes. 1986. Tetrodotoxin-like substance found in the Brazilian frog Brachycephalus ephippium. Toxicon 24: 799-806.

Sueur, J. 2018. Sound Analysis and Synthesis with R. UseR! Book Series. Cham. Springer International Publishing AG. 637 pp.

Tandel, M. C. F. F., S. Loibel, E. G. Oliveira, and C. F. B. Haddad. 2014. Diferenciação de 3 tipos de vocalizações (cantos) na espécie Brachycephalus pitanga. Revista da Estatística da Universidade Federal de Ouro Preto 3: 374-386. 
Bornschein et al.

Verdade, V. K., M. T. Rodrigues, J. Cassimiro, D. Pavan, N. Liou, and M. C. Lange. 2008. Advertisement call, vocal activity, and geographic distribution of Brachycephalus hermogenesi (Giaretta and Sawaya, 1998) (Anura, Brachycephalidae). Journal of Herpetology 42: 542549.
Yeh, J. 2002. The effect of miniaturized body size on skeletal morphology in frogs. Evolution 56: 628-641.

Editor: Ariovalvo A. Giaretta 